University of Rhode Island

DigitalCommons@URI

The Rhode Island Current Conditions Index

Economics

2-2007

\title{
Rhode Island Current Conditions Index - February 2007
}

Leonard Lardaro

University of Rhode Island, lardaro@uri.edu

Follow this and additional works at: https://digitalcommons.uri.edu/ricci

Part of the Econometrics Commons

Terms of Use

All rights reserved under copyright.

\section{Recommended Citation}

Lardaro, Leonard, "Rhode Island Current Conditions Index - February 2007" (2007). The Rhode Island Current Conditions Index. Paper 69.

https://digitalcommons.uri.edu/ricci/69

This Article is brought to you for free and open access by the Economics at DigitalCommons@URI. It has been accepted for inclusion in The Rhode Island Current Conditions Index by an authorized administrator of DigitalCommons@URI.For more information, please contact digitalcommons-group@uri.edu. 


\section{GURRENT EONDITIONS

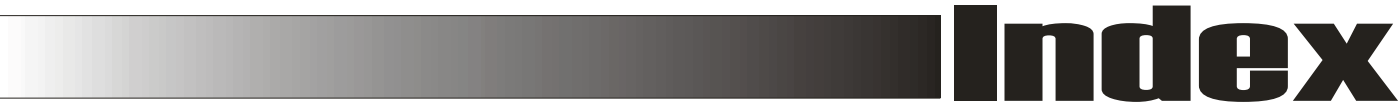

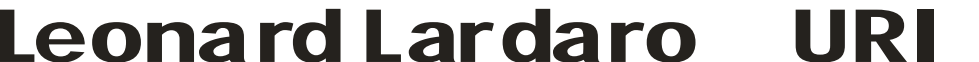

Rhode Island's economic momentum remained somewhat muted in February as the Current Conditions Index was unchanged from its January value of 58, with seven of twelve indicators improving. One reason for the $\mathrm{CCl}$ 's apparent mediocre performance was weather - there was very cold weather and some snow in February that adversely affected some indicators. The indicator most adversely affected by weather was Single-Unit Permits, which reflect new home construction. Yet there were some very strong indicator performances in February, especially Employment Service Jobs, a leading employment indicator. And, like recent months, housing weakness carried over into Retail Sales.

The strongest performances in February were Employment Service Jobs, Private Servicing-Producing Employment, and the Unemployment Rate. Employment Service Jobs, which includes temporary employees, rose by 14.6 percent, its fifth consecutive double-digit increase. Private Service

\begin{tabular}{|c|c|}
\hline \multicolumn{2}{|c|}{ CCI Indicators - \% Change } \\
\hline Government Employment & -1.4 \\
\hline US Consumer Sentiment & $5.0 \mathrm{Y}$ \\
\hline Single-Unit Permits & -43.7 \\
\hline Retail Sales & -1.5 \\
\hline Employment Services J obs & $14.6 \mathrm{Y}$ \\
\hline Priv. Serv-Prod Employment & $2.5 \mathrm{Y}$ \\
\hline Total Manufa & -2.7 \\
\hline Manufacturing Wage & $1.3 \mathrm{Y}$ \\
\hline Labor Force & $0.9 \mathrm{Y}$ \\
\hline Benefit Exhaustions & $-5.2 \mathbf{Y}$ \\
\hline New Claims & 11.6 \\
\hline $\begin{array}{l}\text { Unemployment Rate } \\
Y=1 \text { mproved }\end{array}$ & $-15.4 \mathrm{Y}$ \\
\hline
\end{tabular}

Producing Employment growth was very healthy, at 2.5 percent in February. This indicator has sustained a growth rate in excess of one percent since September of last year. And, our Unemployment Rate fell sharply in February, down from 5.2 percent last February. This is very significant since our labor market performance remains consistent with the downward revisions to last year's data. And, for Rhode Island, it is always important that a declining Unemployment Rate coincide with a rising Labor Force. For February, Rhode Island's Labor Force rose by 0.9 percent compared to last February. However, since last October, the Labor Force has struggled to surpass a one-percent rate of growth.

Single-Unit Permits continued its roller coaster ride in
February, falling by 43.7 percent compared to a year ago. Clearly, this large decline was substantially influenced by weather conditions. Retail Sales declined by 1.5 percent compared to last February, its third decline in the last four months. This too, was adversely affected by February's weather. But US Consumer Sentiment grew by 5.0 percent in February, its sixth consecutive monthly increase.

In February, Rhode Island's manufacturing sector turned in yet another mixed performance. The Manufacturing Wage rose by 1.3 percent, continuing the slowdown in its rate of growth that began last November, while Total Manufacturing Hours fell by 2.7 percent. This occurred even as the workweek rose. Unfortunately, the increase in hours per employee was more than offset by a decline in manufacturing employment.

Government Employment fell again in February, by 1.4 percent, its sharpest decline in well over a year. Expect declines in this indictor to be a regular occurrence in light of our state's budget woes. Finally, a critical labor market "pair" failed to jointly improve for the fourth consecutive month. New Claims for Unemployment Insurance, which measures layoffs, surged by 11.6 percent in February, continuing its recent upward trend, while at the other end of the layoff spectrum, Benefit Exhaustions, which reflects long-term unemployment, fell by 5.2 percent.

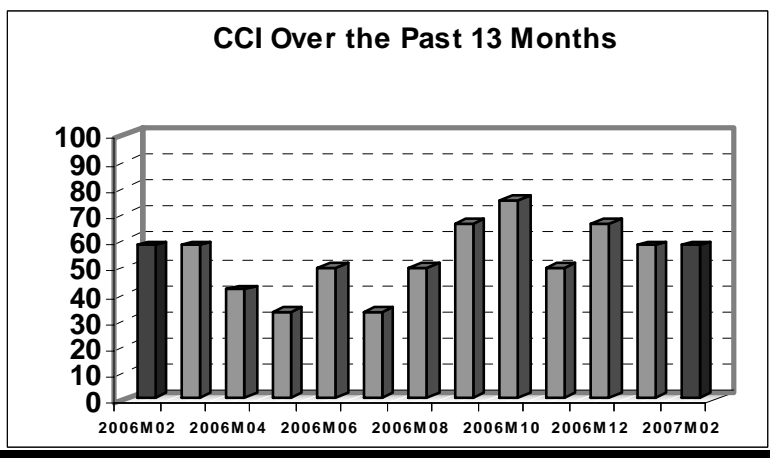

\section{THE BOTTOM LINE}

February's data paints a mixed picture of Rhode Island's economic performance. While there were strong and weak indicator performances, some of the weakness was weather related. This fact along with the solid indicator performances leads me to conclude that Rhode Island's economic momentum was stronger in February than what the $\mathrm{CCl}$ value indicates.

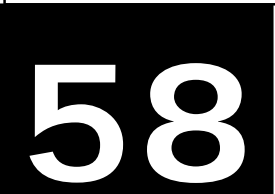

\begin{tabular}{|c|c|c|c|c|c|c|c|c|c|c|c|c|} 
& \multicolumn{2}{c}{ Jan } & Feb & Mar & Apr & May Jun Jul Aug & Sep & Oct & Nov Dec \\
2006 & 58 & 58 & 58 & 42 & 33 & 50 & 33 & 50 & 67 & 75 & 50 & 67 \\
2007 & 58 & 58 & & & & & & & & & & \\
\hline
\end{tabular}

